\title{
Single Donor Plasma
}

National Cancer Institute

\section{Source}

National Cancer Institute. Single Donor Plasma. NCI Thesaurus. Code C133346.

Single donor plasma separated from red donor cells within 26 days after phlebotomy (40 days when citrate phosphate dextrose adenine (CPDA-1) is used as the anticoagulant) and stored at 1-6 degrees $C$. 